\title{
Creating Values: the Entrepreneurial-Science Education Nexus
}

\author{
James P. Davis ${ }^{1}$ \\ Accepted: 25 December 2021 / Published online: 17 January 2022 \\ (c) The Author(s) 2022
}

\begin{abstract}
Values and how values are created in science education are an under-researched field, which is problematic given the importance of epistemic values to the nature of science. From a sociological perspective, values are experienced as emotionally infused ideas with the power to influence choices and actions in everyday situations such as learning through science inquiry. The present study explores the creation of value and values by building on links with entrepreneurial education that are previously explored, but not fully developed, in science education research. Using an entrepreneurial value creation pedagogy (VCP) model as a conceptual framing, this study is situated in a science inquiry project as part of a preservice teachers' course. The study focuses on the question: How are values in science education created by learning through doing an entrepreneurially infused inquiry project? The study illustrates how preservice science teachers create values for self to produce a sense of purpose, how they create value for agency to support action taking in a science investigation, and how they create value for others. Findings illustrate a synthesis of entrepreneurial value creation practices with science inquiry and possibilities for improving understandings about how social, cultural, and epistemic values may be created in science education. Future studies should explore the interdependence between social, cultural, and epistemic values experienced by learners in naturalistic science education contexts. This could involve analysis of epistemic emotions as a constituent of epistemic values.
\end{abstract}

Keywords Education $\cdot$ Entrepreneurial $\cdot$ Epistemic $\cdot$ Science $\cdot$ Values

\section{Introduction}

Connectivity between science education and entrepreneurial education is evident as a novel idea in school and higher education teaching practices over recent years (Deveci \& Seikkukla-Leino, 2016; Martin et al., 2018). Entrepreneurial education involves a broad conceptualisation of both entrepreneurship as organised actions toward innovation and enterprise as the building of personal and human capacities to generate and take action to

James P. Davis

jp.davis@qut.edu.au

1 Queensland University of Technology, Building E, Room E350, Kelvin Grove, Brisbane,

QLD 4059, Australia 
execute opportunities (Penaluna et al., 2020). Subsumed within entrepreneurial education are twenty-first century skills, which are more commonly integrated within science education (cf. Wei et al., 2020). Enterprise or entrepreneurial thinking includes a broader collection of skills, attributes, and behaviours (cf. QAA, 2018) such as risk taking, brainstorming, planning, curiosity, self-confidence, and creativity, plus more (Deveci \& Seikkula-Leino, 2016).

From higher education and industry perspectives, the importance of connecting science with entrepreneurial thinking is viewed from the perspective of job creation (Mbanefo \& Eboka, 2019), the usefulness of commercial thinking for STEM professionals (Watts \& Wray, 2012), and in biotechnology industries where science-driven technologies are commercialised (Aziz \& Rowland, 2018). It is only very recently that entrepreneurial thinking has become a topic of research in relation to K-12 science teachers (Martin, et al., 2018), where entrepreneurial techniques are explored in preservice science teaching contexts (Davis, 2019) and the points of contact between entrepreneurial education and open inquiry methods are explored (Elo \& Kurtén, 2019). In many parts of the world, the uptake of entrepreneurial thinking in science education is sporadic, whereas in the EU and UK, there are examples where entrepreneurial education is embedded across the entire K-12 curriculum (Penaluna et al., 2020), meaning that entrepreneurial connectivity with science education is an emergent research topic (Elo \& Kurtén, 2019).

The present paper focuses on preservice teacher science education with the view to exploring a deeper nexus between entrepreneurial and science education in the form of values and the creation of values. From a sociological perspective, values are emotionally infused ideas with the power to influence choices and actions as part of everyday experiences (Collins, 2004). As a singular concept, value relates to the usefulness of something, and as a plural concept, values are about what counts or matters to people (Lackeus, 2018) in fields such as science. The creation of values is viewed in this study as a pedagogical possibility for shaping learners emotionally infused choices and actions when learning through experiences of science inquiry. As a possible pedagogical achievement, creating values may enhance a learner's sense of purpose, agency, and connectivity with others (Jones et al., 2020) with benefits for learner engagement. Understanding the creation of values as a pedagogical achievement is important for science teachers because socio-cultural values influence science, some values guide science inquiry, and other values are an outcome of science (Allchin, 1999). However, despite a re-emergence of values in science education (Corrigan et al., 2007), our understandings about how values may unfold through the lived experiences of science teaching and learning remain under-researched (Fitzgerald \& Abouali, 2020).

In science education, entrepreneurial value creation practices are described in terms of science creating value for society and industry, where such practices may be taught through inquiry and project-driven science pedagogy (Eltanahy et al., 2020). Further connectivity is made through the nature of science (NOS) that is typically associated with epistemic values (Allchin, 1999) but more recently with the notion of economic value (Kaya et al., 2018). Kaya et al. (2018) explored the connectivity between economic value, entrepreneurial value creation, and the financial systems element of the family resemblance approach to understanding NOS. This perspective of value as a connection between entrepreneurial and science education is limited to the notion of economic value for society and offers limited application for understanding epistemic values. As Eltanahy et al. (2020) and Kaya et al. (2018) have shown, there is clearly some relationship around value and values, which connects entrepreneurial and science education, but that connectivity is not yet fully established, beyond a narrow notion of 
economic value creation. The present paper addresses this limitation in science education research by exploring an innovative entrepreneurial model for value creation illustrated with empirical data from preservice science teacher learning experiences. My research question is as follows: How may values in science education be created by learning through doing an entrepreneurially infused inquiry project?

\section{Literature and Conceptual Framing}

In this section, the entrepreneurial and science education literature is reviewed, providing an overview of ideas related to value and values. I commence with some entrepreneurial perspectives on value and values, followed by literature that looks at values in science education. I adopt a broad view of science education, including notions of science, technology, and socio-scientific issues, as well as learning through projects commonly referred to as STEM education (Ritchie, 2019). Finally I set out a conceptual framing for this study which is a model for a value creation pedagogy (VCP) that synthesises diverse perspectives of value and values in entrepreneurial education (Jones et al., 2020), not previously applied by science education researchers.

\section{Value and Values}

Fundamentally, values are a human phenomenon involving experiences of intertwined emotions and cognitions (Spates, 1983). The power of values, as emotive ideas, derives from the possibility of sanctions from others, concerning choices and actions (Davis \& Bellocchi, 2018). A more specific notion of values is defined in the entrepreneurial field via European policy frameworks, where the foundation of entrepreneurial activity is described as acting upon ideas and transforming them into social, cultural, and/or financial value (Bacigalupo et al., 2016). This definition is broad and points to singular and plural notions of value and values. Here, I outline some basic ideas such as the singular notion of value, the plural notion of values, the process of value creation, and value creation for self and/or others (Lackeus, 2018).

The contemporary idea of value in the singular form is commonly derived from a utilitarian perspective of economics, meaning that something has value if it is perceived to be useful (Lackeus, 2018). Usefulness depends on the perspective of the person determining the value being attributed, and for this reason, it is regarded as subjective. Where a collection of individuals can reach consensus, value as a singular idea lends itself to being objectified and measured. From the utilitarian perspective, the notion of value means we can think of and potentially measure the value of anything, such as the value of science education to society.

The plural idea of values differs from the singular, in terms of their measurability (Stark, 2011). Values are often regarded as defining what counts, or what is important to us, in different situations (e.g., Duschl \& Bybee, 2014). Typically values are determined through making judgements, becoming evident in the outcomes of choices and decisions being made. In many everyday situations, values are often vague, taken for granted, and usually associated with cultural practices (e.g., Davis et al., 2020). The plural approach to exploring values supports thinking about values in science education (cf. Zeidler, 2016). 


\section{Values in Science Education}

The concept of values in science education is succinctly outlined by Allchin (1999) who describes epistemic values as driving choices when making practical scientific decisions. The notion of epistemic values in science education is a translation of various ideas from the philosophy of science (Kuhn, 1998). For example, epistemic values may become evident through school science inquiry where students sanction one another and make choices to use particular science language or refrain from touching objects in a science inquiry (Davis \& Bellocchi, 2018). Such choices are evident in language and actions and may illustrate epistemic values such as objectivity. Importantly, Allchin transfers the notion of values from the philosophy of science, by defining epistemic values in science education as existing in constant interplay with other values that may be social, cultural, or interdisciplinary. Importantly, Allchin's account of values in science education does not separate epistemic values from other forms of societal values, as both are intertwined and interdependent.

Unlike Allchin's (1999) perspective, much of the science education literature addressing values tends to do so implicitly (Zeidler, 2016). An example of this is Duschl and Bybee's (2014) commentary on the US Framework for K-12 Science Education (National Research Council [NRC], 2012) and the Next Generation Science Standards (NGSS Lead States, 2013) where they discuss a 5D model of science inquiry. Duschl and Bybee (2014) broadly define values in the sciences and engineering as understanding what counts or what is important when making decisions during STEM investigations. Within their commentary, they explore the idea of epistemic knowledge as the knowledge required to make decisions about criteria setting, such as what constitutes a fair test, what does precise and accurate measurement mean for specific investigations, what is a systematic observation, and so on. They view epistemic knowledge as an ability to explain how knowledge is created and why students should believe particular STEM findings over alternative explanations. What that paper defines as epistemic knowledge appears to be the outcome of what Allchin describes as the practice of epistemic values.

A broader perspective of values is proposed by Zeidler (2016) who views the implicit position of values and the focus on epistemic values in science education as being too narrow. Zeidler (2016) suggests the NRC/NGSS position on STEM education reinforces a traditional science education perspective where science focuses on fact and leaves other disciplines to focus on values. This issue is explicitly highlighted in the way that NRC (2013) NOS standards define science knowledge as existing independently from humans and specifically removes values from the formation of scientific knowledge. Such a policy position may be viewed as inconsistent with contemporary notions of science philosophy and the human dimension of creating facts from perception (Chalmers, 2013). In educational settings, narrow, value-free notions of science lead to a form of fact-value teaching. Such teaching treats socio-cultural issues, and values arising from these issues, as the context of science education, rather than being at interplay with the very essence of scientific thinking in learning situations (cf. Zeidler, 2016). This critique of the NRC/NGSS position is described as a deficit model of STEM education and suggests the need for a broader collection of values to be appreciated as part of learning through doing open forms of science inquiry. While Zeidler (2016) identifies a need for a broader conceptualisation of values, the contemporary application of entrepreneurial value creation in science education provides yet another narrow conceptualisation of values (cf. Eltanahy et al., 2020; Kaya et al., 2018). To support the present study, a more refined entrepreneurial conceptual framing for value creation is presented for understanding values in science education. 


\section{Conceptual Framing for a Value Creation}

In the absence of a systematic approach to connect social, cultural, and epistemic values in science education, the present study looks to the field of entrepreneurial education where dealing with value and values is a foundational and creative concern. The conceptual framing for the present study is shaped by a model for a value creation pedagogy drawn from the entrepreneurial education literature (Jones et al., 2020). The VCP model supports the present study by improving understandings of value creation during integrated STEM learning experiences. Jones et al. (2020) present a synthesis of value and value creation strategies including Tsunesaburō Makiguchi's (circa. 1871-1944) approach to self-development and the attainment of happiness (cf. Bethel, 1989), Lakeus's (2018) approach that bridges societal value with student value, and various entrepreneurship approaches to value creation for others. Figure 1 shows the creation of value for self in terms of developing a personal sense of purpose. Jones et al. (2020) suggest this may be achieved through a learning journey of ontological discomfort where the learning context is a vehicle for self-learning within a community of peers. Ontological discomfort is about experiential learning, students reflecting on their sense of being and identity, and growing through a process of reflection (Jones et al., 2020).

The development of self and a sense of purpose leads to value creation for agency capability. In the agency field of the model, Jones et al. (2020) borrow from Bandura's (2006) four core properties of human agency: (1) intentionality-purpose and the capacity to blend self-interest with others, (2) forethought, opening the pathway to imagination and possibilities, (3) self-reactiveness enabling the capacity to plan and take action, and (4) self-reflectiveness involving metacognitive and meta-emotive skills for learning through reflection. The development of agency connects with creating value for the self and for others, while simultaneously promoting action taking and reflective learning. Throughout the process of value creation, students are guided through the development of skills leading to cultivated reflection to support life-long learning.

\section{Methods of Data Production}

\section{Methodology}

This is an exploratory, interpretive study where I adopt a phenomenological orientation for understanding values embedded within science learning experiences by extending an existing entrepreneurial model of value creation into a science education context. The

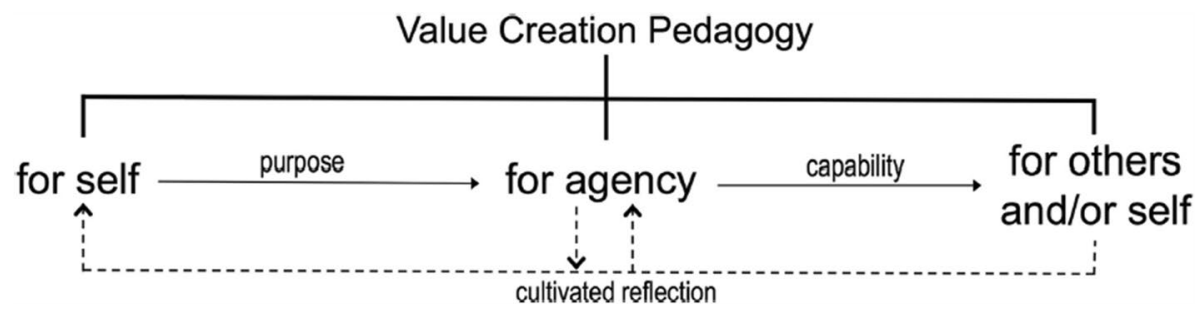

Fig. 1 The value creation pedagogy spectrum (Jones et al., 2020). Republished with permission of Emerald Publishing Ltd, from "Value creation in entrepreneurial education: towards a unified approach" in Education + Training, Jones, C., Penaluna, K., \& Penaluna, A., ahead of print, https://doi.org/10.1108/ET-062020-0165 (2020). Reproduction of Figure 1 requires permission from Emerald 
study is informed by a phenomenology of practice (Bellocchi, 2018; van Manen, 1997) for understanding the salience of values, evident via preservice teachers' reflections on learning experiences. Phenomenological studies are driven by the salience of data determined by the researcher's perspective, defined in the present study by the conceptual framing outlined above. This form of research focuses on a particular context to derive abstract interpretations as a form of theoretical generalisation, which is different from probabilistic generalisation that is driven by sample size (Eisenhart, 2009). Analyses of single cases are common in this form of education research (cf. Simons, 2015) that focuses on understanding particular experiences of phenomena, such as values in a novel context. Similar phenomenological studies in science education have focused on a single teacher (Volkmann \& Zgagacz, 2004), a single teacher and four students in a single lesson (Bellocchi, 2019), and four to five students in a single lesson (Davis \& Bellocchi, 2018; Davis et al., 2020). The purpose of such research is to explore and extend understanding of a complex human phenomenon, such as values, in a different way and in a different context, compared with previous research.

\section{Study Context and Participants}

This is an educator-researcher led study, conducted in an initial teacher education program in Australia. The study focuses on 4th-year preservice teachers (PSTs) undertaking a capstone course comprising a 13-week STEM investigation project. PSTs had a course major for senior secondary school teaching, drawn from mathematics and/or one of the sciences, which included physics, biology, chemistry, or earth sciences. The course comprised of 47 PSTs from which 34 gave consent to participate in the study. Final participants who had their data analysed in this study are described in Table 1 . The study was approved by a university human research ethics committee.

\section{Preservice Teacher STEM Investigation Project}

PSTs attended weekly tutorials in the first 4 weeks focusing on entrepreneurial thinking and STEM project planning. This was followed by 9 weeks of inquiry. Project topics were generated by PSTs thinking about complex global issues and simplifying these into a localised and manageable sub-theme for investigation through a STEM perspective. The issues, topics, and methods generated by PSTs in this study are shown in Table 1.

Values and actions for creating values were made explicit by teaching entrepreneurial thinking including enterprise skills, attributes, and behaviours (QAA, 2018), such as taking the initiative, pivoting and adapting, story-telling, risk taking, open mindedness, selfefficacy, decision-making, identifying opportunities, creative problem-solving, and so on. In addition, three practical entrepreneurship techniques were taught: (1) problem validation (Davis, 2019), (2) the lean startup build-test-learn design cycle (Ries, 2014), and (3) persona definition (Aulet, 2013). Problem validation is about testing a new problem idea with possible early adopters or end users. Persona definition is a technique for identifying the potential end users. The build-test-learn design cycle uses end-user validation to co-design solutions. The application of these techniques in STEM education is described in the entrepreneurial education literature (Davis, 2019). PSTs were assessed via (1) a group-generated project proposal at week 4, which included aspects of entrepreneurial validation data, (2) a group presentation of the STEM project at week 13, and (3) an individual written reflective journal about learning experiences throughout the project. 
Table 1 Issues, topics, and methods

\begin{tabular}{|c|c|c|c|}
\hline Group & Complex issue & Inquiry topic & Inquiry methods \\
\hline A & $\begin{array}{l}\text { Global Waste Management } \\
\text { (At the time China had ceased } \\
\text { importing Australia's recycle } \\
\text { waste) }\end{array}$ & $\begin{array}{l}\text { Understanding and improving } \\
\text { waste disposal practices of } \\
\text { the on-campus university } \\
\text { population } \\
\text { Participant Pseudonyms: } \\
\text { Jean, Sally, and Emma. All } \\
\text { females, science/mathemat- } \\
\text { ics teaching areas }\end{array}$ & $\begin{array}{l}\text { (1)Empirical scientific study of } \\
\text { waste disposal practices on a } \\
\text { single university campus, via } \\
\text { garbage bin audits and surveys } \\
\text { (2)Investigation of specific waste } \\
\text { materials and possible waste } \\
\text { management pathways } \\
\text { (3)Development of a digital } \\
\text { solution in the form of a } \\
\text { mobile application to educate } \\
\text { the campus population and } \\
\text { guide waste disposal decisions } \\
\text { with different waste materials } \\
\text { (4)Applied entrepreneurial tech- } \\
\text { niques in mobile application } \\
\text { validation and development }\end{array}$ \\
\hline B & $\begin{array}{l}\text { Traffic Congestion in Large } \\
\text { Cities }\end{array}$ & $\begin{array}{l}\text { Addressing overcrowded } \\
\text { train services in Brisbane, } \\
\text { Australia } \\
\text { Participant pseudonym: Mike's } \\
\text { data is analysed in this study. } \\
\text { There was one other male } \\
\text { and two female PSTs in this } \\
\text { group with teaching areas in } \\
\text { science/mathematics }\end{array}$ & $\begin{array}{l}\text { (1)Focus on a single train line } \\
\text { service } \\
\text { (2)Empirical study of train } \\
\text { service usage during peak hour } \\
\text { by collecting passenger data } \\
\text { at each station over a 5-day } \\
\text { period } \\
\text { (3)Developed mathematical } \\
\text { modelling of passenger move- } \\
\text { ments } \\
\text { (4)Application of empirical data } \\
\text { to develop alternative service } \\
\text { usage models assuming dif- } \\
\text { ferent technologies such as } \\
\text { smaller, more frequent, and } \\
\text { driverless trains } \\
\text { (5)Applied entrepreneurial } \\
\text { techniques in the initial valida- } \\
\text { tion of the problem with train } \\
\text { service customers }\end{array}$ \\
\hline
\end{tabular}

\section{Data Collection and Selection}

Data were collected in this study from PSTs' reflective journals (cf. Korthagen \& Vasalos, 2005) that addressed the marking criteria noted in Table 2, with varying degrees of depth. Four journals were selected for detailed analysis because they presented reflections on values at a depth that represented core reflection (Korthagen \& Vasalos, 2005). Core reflection is deeper than objective recollections of learning, by involving a subjective depth that enhances change and professional growth. With respect to the phenomenon of values, only four PST journals achieved core reflection. As shown in Table 1, three of these journals are related to group A and one related to a PST in group B. 
Table 2 Assessing values via reflective writing

\begin{tabular}{|c|c|}
\hline Marking criteria extract & Interface between actions, values, and assessment \\
\hline $\begin{array}{l}\text { "...evidence of reflection on the pedagogical framing of } \\
\text { failure in the context of STEM investigations aligned } \\
\text { with entrepreneurial thinking and validated learning" }\end{array}$ & $\begin{array}{l}\text { (1)Validated learning involves engaging with } \\
\text { project end users at the start and throughout } \\
\text { the projects for the purposes of aligning project } \\
\text { values and making project decisions and } \\
\text { choices } \\
\text { (2)Explicit teaching of entrepreneurial techniques } \\
\text { for creating value and values, supported learn- } \\
\text { ers' reflective thinking and writing }\end{array}$ \\
\hline $\begin{array}{l}\text { "...evidence of ethical understanding with reference } \\
\text { to...... values, rights, responsibilities and different } \\
\text { points of view" }\end{array}$ & $\begin{array}{l}\text { (1)Learners were assessed for reflection on ethi- } \\
\text { cal understanding of values that informed their } \\
\text { team relationships, how they made choices to } \\
\text { support team objectives, team contributions } \\
\text { (2)Learners were assessed on how they reflected } \\
\text { on engagement with others outside their team } \\
\text { such as project end users }\end{array}$ \\
\hline
\end{tabular}

\section{Data Analysis and Data Quality}

The study generated qualitative data that was analysed using an inductive-deductive thematic analysis (Braun \& Clarke, 2006) with an interpretive phenomenological approach for understanding learners' experiences. This means that themes may be understood as the structures of the phenomenon within the study context and are not highly abstract or rigidly defined as would be expected in the formation of psychological constructs (van Manen, 1997). My quality criteria for evaluating data are drawn from the fourth-generation evaluation framework of trustworthiness and authenticity (Guba \& Lincoln, 1989). Criteria such as credibility, transferability (i.e., theoretical generalizability), dependability, confirmability, and authenticity were applied. For example, a research assistant was employed during the data analysis to perform initial selection of reflective journal data that addressed categories related to the topic being investigated (e.g., ethical relationships, values, or validated learning). These initial data were reviewed and tested for confirmability by the author. Further coding was applied using the conceptual framing outlined in this paper that lends transparency and dependability to the analytical processes. Authenticity is also achieved by drawing data from PSTs' written reflections as part of their assessment artefacts derived through their experiences of STEM investigation projects.

\section{Findings}

This study focuses on the experiences of four preservice teachers with the pseudonyms of Jean, Sally, Emma, and Mike, who worked in teams comprising a combination of peers with science and mathematics education backgrounds. Findings provide evidence of connectivity between science education and entrepreneurial education by exploring values and the creation of values through entrepreneurial science inquiry processes and learning experiences. The phrase entrepreneurial science inquiry is developed in this study to describe the connectivity between entrepreneurial and scientific thinking through inquiry practices. Table 3 summarises a sample of data cross-referenced in 


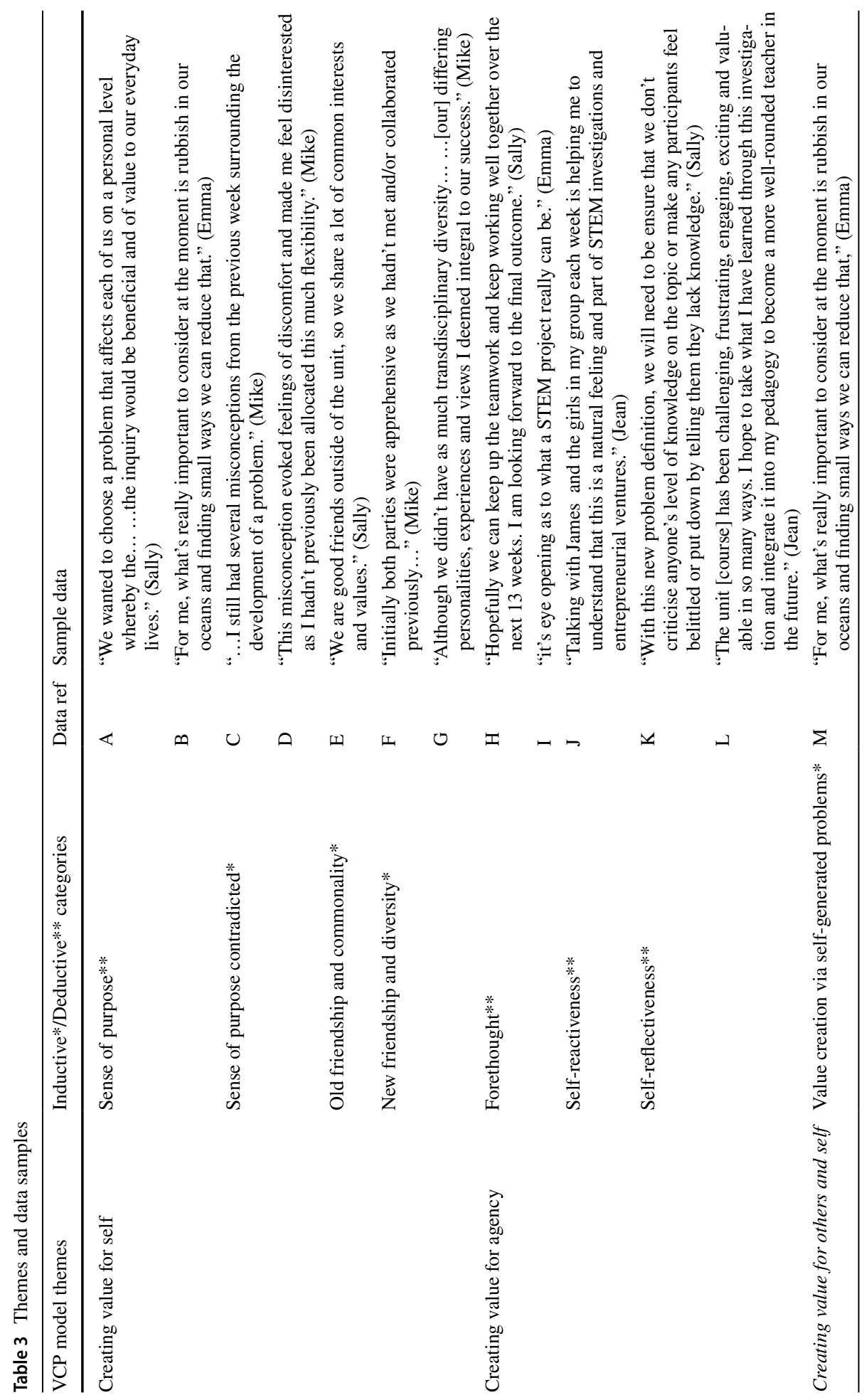




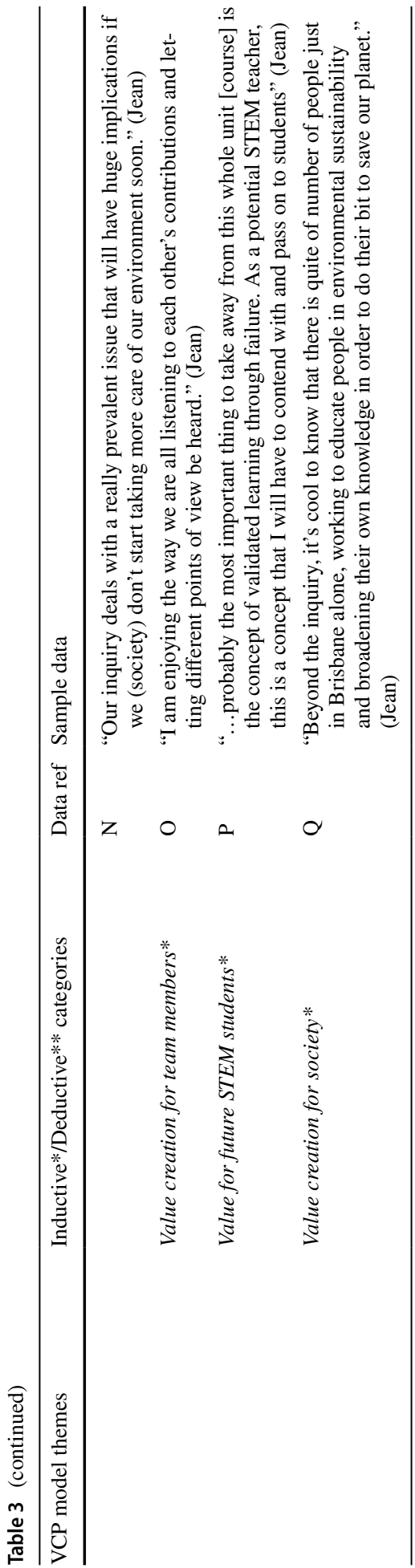


these findings using bracketed notation such as "(Table 3: C)". Data are presented in this way due to publisher's word length limitations.

Data are arranged within the deductive themes of creating value for self, creating value for agency, and creating value for others and self from the VCP model (Fig. 1). Within these themes, data is represented across a combination of categories, some of which are described deductively from the VCP model and others being described inductively from the data. The inductive categories illustrate possible modifications to the VCP model, contributing to the meaning of the model within the context of entrepreneurial science inquiry.

\section{Creating Values for Self}

The VCP model was conceptually developed by Jones et al. (2020), and it describes how the core feature of creating value for self may be evident through the development of a sense of purpose. Developing a sense of purpose is not always a simple or linear process. This means that learners may experience a form of ontological discomfort where their sense of purpose is challenged when engaging in entrepreneurial activities. Ontological discomfort was evident in Mike's reflection about understanding the process of problem or idea validation that he reflected on with "...I still had several misconceptions from the previous week surrounding the development of a problem" (Table 3: C). This issue became a focus for Mike that was interpreted as an example of ontological discomfort, evident with his further statement that, "This misconception evoked feelings of discomfort and made me feel disinterested as I hadn't previously been allocated this much flexibility" (Table 3: D). This statement evidences Mike's emotive-affective experiences of an epistemic situation involving a highly flexible open-inquiry project. As Mike and his group defined their project problem, Mike's discomfort was resolved as he overcame the challenge that confronted him. This example of ontological discomfort is important because it illustrates an intersection between social values about one-self and the demands of an epistemic situation where epistemic values are embedded in the educational context. In this situation, the learner was positioned to experience a highly flexible inquiry situation where learners' choices and decisions about generating a science inquiry idea needed to be performed and experienced. In this way, social values about the self and the demands of epistemic values became a source of ontological discomfort that contributed to the project process. It is worth noting, however, that not all learners reflected on such experiences, with some finding the entrepreneurial science inquiry process a more linear learning experience for building a sense of purpose (Table 3: A/B).

A further finding of the present study extends the VCP model by exploring the place of friendship in developing a sense of self and purpose. The category of an old friendship within group A (Table 1) was associated with the development of a shared sense of purpose through common values and common ideas being evident to learners (Table 3: E). In contrast the category of a new friendship within group B (Table 1) was associated with a recognition of diversity and getting to know someone who was different from one's self. Through the group B example, there was evidence of learners appreciating differences in ideas, which were valued and attributed by learners as supporting their success in the context of innovation (Table 3: F/G). 


\section{Creating Values for Agency}

The VCP model conceptualises creating values for agency by drawing on Bandura's (2006) core properties for human agency. In the present study, there were three of these core properties evident in the data analyses. Specifically, these included forethought (Table 3: H/I), self-reactiveness (Table 3: J), and self-reflectiveness (Table 3: K/L). There were no inductive categories generated in relation to agency.

\section{Creating Value for Others and Self}

This theme within the VCP model does not specify particular categories but instead describes the commonly regarded approaches for adding value to others and self that are typically associated with entrepreneurial activities. In the context of entrepreneurial science inquiry, the data analysis has generated new categories that identify the creation of value and values in relation to others and self. These include value for self through the self-generation of inquiry topics (Table 3: M/N). This was an important feature of the open inquiry structure and the entrepreneurial techniques of idea generation that created value in these science projects. A further category was value creation for team members (Table 3: O), which was related to the ethical consideration of appreciating the ideas of others. A further category was value creation for future science students as participants reflected on their own experiences and projected these to make meaning in relation to their future roles as science teachers (Table 3: P). Finally, the entrepreneurial practices of validated learning that were embedded across the science inquiry projects contributed to learner experiences. These experiences were evident with reflections focusing on value creation for society and in the way learners thought about complex issues and localised topics through their projects (Table 3: Q).

\section{Discussion}

In this section, I address the research question by exploring learner experiences of value creation practices and how social, cultural, and epistemic values in science education may become evident through entrepreneurial science inquiry. As indicated by the earlier discussion of the literature, entrepreneurial education successfully focuses on the simultaneous creation of social, cultural, and financial value (Bacigalupo et al., 2016). Understanding value, values, and how values are created is a core feature of entrepreneurial education. In contrast, science education is often criticised (cf. Zeidler, 2016) for struggling to move beyond an outdated belief that science is or should be value-free (NRC, 2012, 2013; NGSS, 2013), with the exception of narrowly defined epistemic values grounded in the philosophy of science (Duschle \& Bybee, 2014). The present study explores possibilities for learning from entrepreneurial education, by integrating entrepreneurial value creation practices with science inquiry. This integration is achieved by seeking to create social, cultural, and epistemic values as an authentic outcome of learning through science inquiry experiences. Here I provide a window into what that may look like through the lens of the VCP model (Jones et al., 2020). 


\section{Value Creation Practices}

The participants in this study engaged with a collection of entrepreneurial value creation practices such as validated learning, design thinking, and persona definition as described above in the "Methods of Data Production" section. These practices shaped learner experiences as evidenced by their reflective accounts toward understanding their own values through a sense of self in relation to the science project, the values of peers, and the values of potential end users of science.

The creation of values to support a sense of self was very prominent in the data, and an example of this is the reflective statement that "We wanted to choose a problem that affects each of us on a personal level..." (Table 3: A/B). This type of statement indicates learner values related to the generation of a topic where group members could share a deep personal attachment to the ideas being investigated. This form of connectivity with the inquiry topic fosters connectivity with authentic contexts valued by particular learners (cf. Ritchie, 2019). The emphasis on authenticity and context also connects with an existing body of research in science education on context-based learning (cf. King \& Henderson, 2018). However, the inclusion of entrepreneurial practices situates the learner with new practices for improving agency, for understanding the values of self and others, and for making choices about topics. In a preservice teacher context, this experience enables learners to understand authenticity and context in science education by reflecting on their own values and how these may inform their future practices as science teachers (see Table 3: P).

The entrepreneurial value creation practices experienced by learners in this study also contribute to a sense of value creation for society where learners experience the benefits of their entrepreneurial science inquiry because they connect with end users. This was achieved by getting out of the lab (cf. Aulet, 2013), which is an entrepreneurial practice aimed at validating ideas for their social and cultural value, before investing time and effort in the lab (see Table 3: Q). In this way, learners do not perform science investigations in an isolated values-free environment (cf. NRC, 2013), because what should be investigated and what is valued as a potential science outcome is progressively validated for social and cultural relevance (cf. Zeidler, 2016). Through the blending of entrepreneurial value creation and science inquiry practices, learners are constantly reflecting on the values of others (see Table 3: K/L) and how their solutions, inquiry methods, and project outcomes are shaped, to optimise the social and cultural contribution to others (see Table 3: M/N/O/P/Q). In this way, entrepreneurial science inquiry foregrounds social and cultural values during the process of inquiry activities involving the application of epistemic values. This connectivity across different types of values is a key topic for future investigation.

\section{Social, Cultural, and Epistemic Values in Science Education}

This study opens possibilities for understanding better the connectivity between social, cultural, and epistemic values, relevant to science teacher education and school contexts. In this section, I draw together examples from the data where social and cultural values became evident and relatable to contemporaneous epistemic values.

One of the conceptual ideas in the VCP model (Jones et al., 2020) contributing to the reshaping of values is the notion of ontological discomfort. For example, Mike notes "...feelings of discomfort... as I hadn't previously been allocated this much flexibility" (see Table 3: D). Experiences of discomfort in the present entrepreneurial science inquiry projects may be 
attributed to the complexities of authentic, open-ended science inquiry. In the present study, this complexity was planned to elicit learner experiences of uncertainty and small failures that are a feature of both entrepreneurial (QAA, 2018) and science education (Simpson \& Maltese, 2016). From an entrepreneurial perspective, the rationale for creating such experiences is to develop the confidence and resilience of learners to overcome risk and uncertainty (Jones, 2019). In the context of teaching through science inquiry, this positioning of learners aims to engage them with knowledge creation and epistemic values involving complexity and authenticity (McLaughlin \& MacFadden, 2014). By situating learners within the uncertainty of entrepreneurial science inquiry, the present study illustrates the potential benefits of blending experiences of social values relating to the sense of self and epistemic values related to understanding and making choices in a complex inquiry context. As an exploratory illustration of social and epistemic values, this study highlights the potential for more substantial empirical research and theoretical development in this emergent field of values in science education.

A further contribution of this study toward understanding the integration of social, cultural, and epistemic values in science education is evident through the inductive generation of the categories of old friendships and new friendships (Table 3: E/F/G). In previous STEM education, research friendship groups are associated with a willingness to ask questions and contribute ideas (Takeuchi, 2016). In the present study, Emma, Sally, and Jean's group (group A, Table 1) commented that they were "...good friends outside of the unit [i.e., course], so we share a lot of common interests and values" (see Table 3: E). Clearly for this group, their values toward friendship were viewed explicitly by them as influencing the choices they made in shaping the direction of their science inquiry topic and their choice to pursue an activist form of science inquiry (Bencze \& Alsop, 2014) where they sort to educate the public as part of their project (group A, Table 1).

In contrast Mike reflected that "initially both parties were apprehensive as we hadn't met and/or collaborated previously..." as noted a process of getting to know each other, which is categorised in the findings as a new friendship (Table 3: F). Mike also reflected on the diversity of his group members' with "differing personalities, experiences and views I deemed integral to our success" (see Table C: G), because they were able to critically analyse their project and discuss issues from different perspectives. In his situation, the social and cultural diversity of Mike's group was viewed by him as contributing to a diversity of ideas generated throughout the project. The diversity of ideas during inquiry processes in STEM education was recently explored as experiences of harmony in ideas, where diverse ideas may lead to the formation of new shared ideas through processes of social interaction (Davis et al., 2020). In this way, diversity of ideas leading to harmonised shared ideas may be observable through the particular social practices of science inquiry groups where epistemic values are evident through micro-social actions and choices.

This brief exploration of social, cultural, and epistemic values highlights some important connections that may be possible through practices of entrepreneurial science inquiry. This study suggests an understanding of the interplay between different values where learners engage with and reflect on entrepreneurial practices during science inquiry. The examples highlighted in this study are also indicative of possible ways learner reflection on social and cultural values may contribute to epistemic outcomes in science inquiry. 


\section{Conclusion}

This study explores the nexus between entrepreneurial and science education by seeking to understand the creation of social, cultural, and epistemic values through entrepreneurial value creation practices. The focus on values and creating values illustrates the entrepreneurial-science connectivity that extends beyond a narrow view of economic values as a rationale for science education to exist (cf. Ritchie, 2019). The present study illustrates how entrepreneurial value creation practices and scientific practices may shape new forms of epistemic values grounded in socio-scientific issues and the social and cultural values of learners (cf. Allchin, 1999; Zeidler, 2016). For science education practice and research, the VCP model and the process of reflection for learning lay a foundation for new thinking about epistemic values. Epistemic values in science education research are most often present in a taken for granted way, as a vague process of making choices for what matters when creating facts. By synthesising the entrepreneurial value creation practices with learning experiences through science inquiry, it may be possible to explicitly teach and thoroughly research the creation of social, cultural, and epistemic values in science education. The present exploratory study points to some possibilities for showing how these processes may unfold in research and in practice, to eventually enhance science teachers' understandings of values.

\section{Limitations}

This is a highly innovative study exploring the nexus between entrepreneurial and science education in an authentic inquiry context with preservice teachers. The paucity of studies that focus on values in entrepreneurial-science education means that the probabilistic generalizability of findings is limited; however, the present study enables theoretical generalisations through the description of phenomenological themes. A further limitation of this exploratory study is the reliance on learner reflective journals that becomes problematic if students do not engage with core reflection, which is necessary for professional change. A more thorough understanding of learners' values experienced in science education could be achieved with a multi-method study that includes interviews, focus groups, and observation of learner interactions. I acknowledge the place of myself in the research process and have addressed this by being explicit about analytical perspectives such as the conceptual framing and methods, consistent with phenomenological studies in science education contexts.

\section{Future Research}

Future research should apply the VCP model as a conceptual framework in a larger study of values from an empirical perspective (cf. Fitzgerald \& Abouali, 2020). The foundational definition of values, as ideas infused with emotion (Collins, 2004), is a useful start point for building and broadening studies of epistemic values and for understanding value creation processes through learning experiences. It is a useful start point because the challenge of studying values lies in the analysis of the emotional infusion around ideas. Such future research may be supported by current science education research methodologies developed for the study of emotive experiences in naturalistic contexts over recent years (Bellocchi, 
2017; Davis \& Bellocchi, 2018; Davis et al. 2020). It is timely that the field of science education starts to consider its own notions of epistemic values beyond those of science and the philosophy of science, in order to broaden the appeal of science education to students, citizens, and prospective science teachers. Finally, while this exploratory study focused on preservice teachers, the extension of values research into school science contexts would add value to the field of science education.

Funding Open Access funding enabled and organized by CAUL and its Member Institutions.

Open Access This article is licensed under a Creative Commons Attribution 4.0 International License, which permits use, sharing, adaptation, distribution and reproduction in any medium or format, as long as you give appropriate credit to the original author(s) and the source, provide a link to the Creative Commons licence, and indicate if changes were made. The images or other third party material in this article are included in the article's Creative Commons licence, unless indicated otherwise in a credit line to the material. If material is not included in the article's Creative Commons licence and your intended use is not permitted by statutory regulation or exceeds the permitted use, you will need to obtain permission directly from the copyright holder. To view a copy of this licence, visit http://creativecommons.org/licenses/by/4.0/.

\section{References}

Allchin, D. (1999). Values in science: An educational perspective. Science \& Education, 8, 1-12.

Aulet, B. (2013). Disciplined entrepreneurship: 24 steps to a successful startup. Wiley.

Aziz, A. A. A., \& Rowland, S. (2018). The entrepreneurship skills that biotechnology graduates need: Findings from entrepreneurial employees in a developing economy. Entrepreneurship Education, 1, 61-83. https://doi.org/10.1007/s41959-018-0006-7

Bacigalupo, M., Kampylis, P., Punie, Y., \& Van den Brande, G. (2016). EntreComp: The entrepreneurship competence framework. Luxembourg: Publication Office of the European Union; EUR 27939 EN; https://doi.org/10.2791/593884

Bandura, A. (2006). Towards a psychology of human agency. Perspectives on Psychological Science, 1(2), $164-180$.

Bellocchi, A. (2017). Interaction ritual approaches to emotion and cognition in science learning experiences. In A. Bellocchi, C. Quigley, \& K. Otrel-Cass (Eds.), Exploring emotions, aesthetics and wellbeing in science education research (pp. 85-105). Springer. https://doi.org/10.1007/978-3-319-43353-0_5

Bellocchi, A. (2018). Lived experiences of social bonds in science classrooms. In S. M. Ritchie \& K. G. Tobin (Eds.), Eventful learning: Learner emotions (pp. 217-232). Brill. https://doi.org/10.1163/97890 04377912_011

Bellocchi, A. (2019). Early career science teacher experiences of social bonds and emotion management. Journal of Research in Science Teaching, 56, 322-347. https://doi.org/10.1002/tea.21520

Bencze, L., \& Alsop, S. (Eds.). (2014). Activist science and technology education. Springer.

Bethel, D. (1989). Education for creative living: Ideas and proposals of Tsunesaburo Makiguchi. State University Press.

Braun, V., \& Clarke, V. (2006). Using thematic analysis in psychology. Qualitative Research in Psychology, 3(2), 77-101. https://doi.org/10.1191/1478088706qp063oa

Chalmers, A. (2013). What is this thing called science? University of Queensland Press.

Collins, R. (2004). Interaction ritual chains. Princeton University Press.

Corrigan, D., Dillon, J., \& Gunstone, R. (2007). The re-emergence of values in science education. BrillSense. https://doi.org/10.1163/9789087901677

Davis, J. P. (2019). Preservice teacher learning experiences of entrepreneurial thinking in a STEM investigation. Entrepreneurship Education, 2, 1-17. https://doi.org/10.1007/s41959-019-00009-0.

Davis, J. P., \& Bellocchi, A. (2018). Objectivity, subjectivity, and emotion in school science inquiry. Journal of Research in Science Teaching, 55, 1419-1447. https://doi.org/10.1002/tea.21461.

Davis, J. P., Du, J., Tang, J.-H., Qiao, L., Liu, Y.-Q., \& Chiang, F.-K. (2020). Uniformity, diversity, harmony and emotional energy in a Chinese STEM Classroom. International Journal of STEM Education. https://doi.org/10.1186/s40594-020-00232-5. 
Deveci, I., \& Siekkula-Leino, J. (2016). Finnish science teacher educators' opinions about the implementation process related to entrepreneurship education. Electronic Journal of Science Education, 20(4), $1-20$.

Duschl, R. A., \& Bybee, R. W. (2014). Planning and carrying out investigations: An entry to learning and to teacher professional development around NGSS science and engineering practices. International Journal of STEM Education, 1, 12. https://doi.org/10.1186/s40594-014-0012-6

Eisenhart, M. (2009). Generalization from qualitative inquiry. In K. Ercikan, \& W-M. Roth (Eds.). Generalizing from education research: Beyond qualitative and quantitative polarization (pp. 51-66). London, UK: Routledge.

Elo, J., \& Kurtén, B. (2019). Exploring points of contact between enterprise education and open-ended investigations in science education. Education Inquiry. https://doi.org/10.1080/20004508.2019.16339 03

Eltanahy, M., Forawi, S., \& Mansour, N. (2020). STEM leaders and teachers views of integrating entrepreneurial practices into STEM education in high school in the United Arab Emirates. Entrepreneurship Education, 3, 133-149. https://doi.org/10.1007/s41959-020-00027-3

Fitzgerald, A., \& Abouali, D. (2020). Exploring values through lived experiences of the World Heritage Site of Petra: A case study. In D. Corrigan, C. Buntting, A. Fitzgerald, \& A. Jones (Eds.), Values in science education: The shifting sands (pp. 211-224). Springer. https://doi.org/10.1007/978-3-030-42172-4

Guba, E., \& Lincoln, Y. (1989). Fourth generation evaluation. Sage.

Jones, C. (2019). How to teach entrepreneurship. Edward Elgar.

Jones, C., Penaluna, K., \& Penaluna, A. (2020). Value creation in entrepreneurial education: Towards a unified approach. Education + Training, 63, 101-103. https://doi.org/10.1108/ET-06-2020-0165

Kaya, S., Erduran, S., Birdthistle, N., \& McCormack, O. (2018). Looking at the social aspects of nature of science in science education through a new lens: The role of economics and entrepreneurship. Science \& Education, 27, 457-478. https://doi.org/10.1007/s11191-018-9990-y

King, D., \& Henderson, S. (2018). Context-based learning in the middle years: Achieving resonance between the real-world field and environmental science concepts. International Journal of Science Education, 40(10), 1221-1238. https://doi.org/10.1080/09500693.2018.1470352

Korthagen, F., \& Vasalos, A. (2005). Levels in reflection: Core reflection as a means to enhance professional growth. Teachers and Teaching, 11, 47-71. https://doi.org/10.1080/135406004200033 7093

Kuhn, T. S. (1998). Objectivity, value judgment and theory choice. In M. C. Curd \& J. A. Cover (Eds.), Philosophy of science: The central issues (pp. 102-118). Norton.

Lackeus, M. (2018). What is value? - A framework for analyzing and facilitating entrepreneurial value creation. Uniped, 41(1), 10-28. https://doi.org/10.18261/ISSN.1893-8981-2018-01-02

Martin, A. M., Abd-El-Khalick, F., Mustari, E., \& Price, R. (2018). Effectual reasoning and innovation among entrepreneurial science teacher leaders: A correlational study. Research in Science Education, 48, 1297-1319. https://doi.org/10.1007/s11165-016-9603-1

Mbanefo, M. C., \& Eboka, O. C. (2019). Acquisition of innovative and entrepreneurial skills in basic science education for job creation in Nigeria. Science Education International, 28(3), 207-213.

McLaughlin, C. A., \& MacFadden, B. J. (2014). At the elbows of scientists: Shaping science teachers' conceptions and enactment of inquiry-based instruction. Research in Science Education, 44, 927-947. https://doi.org/10.1007/s11165-014-9408-z

National Research Council. (2012). A Framework for K-12 Science Education: Practices, Crosscutting Concepts, and Core Ideas. Committee on a Conceptual Framework for New K-12 Science Education Standards (Board on Science Education, Division of Behavioral and Social Sciences and Education). The National Academies Press.

National Research Council. (2013). Next generation science standards for states by states: Appendix H. Understanding the scientific enterprise: The nature of science in the next generation science standards. Retrieved August 18, 2020, from: https://www.nap.edu/catalog/18290/next-generation-scien ce-standards-for-states-by-states.

NGSS Lead States. (2013). Next Generation Science Standards: For States, By States. The National Academies Press.

Penaluna, A., Penaluna, K., \& Polenakovikj, R. (2020). Developing entrepreneurial education in national school curricula: Lessons from North Macedonia and Wales. Entrepreneurship Education, 3, 245263. https://doi.org/10.1007/s41959-020-00038-0

Quality Assurance Agency (QAA) (2018). Enterprise and entrepreneurship education: guidance for UK higher education providers. Retrieved August 30, 2020, from http://www.qaa.ac.uk/docs/qaas/ enhancement-and-development/enterprise-and-entrpreneurship-education-2018.pdf?sfvrsn=15f $1 \mathrm{f}$ 981_8 
Ries, E. (2014). The lean startup: How today's entrepreneurs use continuous innovation to create radically successful businesses. Crown Business.

Ritchie, S. M. (2019). STEM education. Oxford University Press. https://doi.org/10.1093/acrefore/97801 90264093.013.237

Simons, H. (2015). Interpret in context: Generalising from the single case in evaluation. Evaluation, 21, 173-188.

Simpson, A., \& Maltese, A. (2016). Failure is a major component of learning anything: The role of failure in the development of STEM professionals. Journal of Science Education and Technology, 26, 223-237. https://doi.org/10.1007/s10956-016-9674-9

Spates, J. L. (1983). The sociology of values. Annual Reviews of Sociology, 9, 27-49.

Stark, D. (2011). The sense of dissonance: Accounts of worth in economic life. Princeton.

Takeuchi, M. A. (2016). Friendships and group work in linguistically diverse mathematics classrooms: Opportunities to learn for English language learners. Journal of the Learning Sciences, 25, 411437. https://doi.org/10.1080/10508406.2016.1169422

Van Manen, M. (1997). Researching lived experience: Human science for an action sensitive pedagogy. Left Coast Press.

Volkmann, M. J., \& Zgagacz, M. (2004). Learning to teach physics through inquiry: The lived experience of a graduate teaching assistant. Journal of Research in Science Teaching, 41, 584-602.

Watts, C. A., \& Wray, K. (2012). Using toolkits to achieve STEM enterprise learning outcomes. Education \& Training, 54(4), 259-277. https://doi.org/10.1108/00400911211236118

Wei, B., Lin, J., Chen, S., \& Chen, Y. (2020). Integrating $21^{\text {st }}$ Century competencies into a K-12 curriculum reform in Macau. Asia Pacific Journal of Education. https://doi.org/10.1080/02188791.2020.1824893

Zeidler, D. L. (2016). STEM education: A deficit framework for the twenty first century? A sociocultural socioscientific response. Cultural Studies of Science Education, 11, 11-26. https://doi.org/10.1007/ s11422-014-9578-Z

Publisher's Note Springer Nature remains neutral with regard to jurisdictional claims in published maps and institutional affiliations. 